\title{
Unmarried and Married in Jane Austen's Pride and Prejudice
}

\author{
Eljvira Kica \\ South East European University, Tetovo, R. Macedonia
}

*Corresponding Author: Eljvira Kica, South East European University, Tetovo, R. Macedonia

\begin{abstract}
Jane Austen's Pride and Prejudice is a novel which is based on the authentic situations of the eighteenth-nineteenth century England. The novel shows clearly how life was during this period, how the choice of the partner was made, the discrimination of females and their absence in important and decisive events. In her novel, Austen focuses in marriages based on economical conditions, considering marriage as a business in which most of the families of the eighteenth century were involved. Most of her characters are preoccupied about the harsh reality of the marriage market, most of the marriages take place in a situation where parents decide what is good or bad for young girls or boys, and most of the marriages take place within a young age, especially for girls. This paper relies with the ways how Jane Austen describes the conditions of unmarried and married women in Pride and Prejudice, and their choice of a partner; how Jane Austen compares the married and unmarried couples in her novel with the real situation of the eighteenth century in British society; how Jane Austen describes the people who find a match for their children, friends or relatives and the message that Jane Austen conveys through her novel.
\end{abstract}

Keywords: Marriage, couples, unmarried, money, love, class, interest, society.

\section{INTRODUCTION}

Jane Austen's Pride and Prejudice is a novel which tells the story of Elizabeth Bennet, the main character of the story, and her family in the period of the eighteenth- nineteenth century. The Bennets had five daughters, Jane, Elizabeth, Mary, Kitty and Lydia and since these sisters did not possess any valuable property, their only way was a marriage with someone of a great property. In her novel, Jane Austen involved different kinds of marriages, such as matched marriages, romantic love marriages and also elopement of lovers. Since most of the marriages of the eighteenth century were decided by the parents and "women were expected to behave modest, submissive, and, most important: incapable of independent thought" (Strohmeier, 2013). "Austen's work Pride and Prejudice is a novel that unites the main possibilities of finding happiness through marriage" (Strohmeier, 2013). Not being satisfied with the current situation of marriages happening in the eighteenth century ,Austen does not directly express this dissatisfaction but "she makes use of declarations and behavior of her women characters to assert it" (Dobosiova, 2006).

Since most of the novel goes around the marriage of Bennet sisters in order to find the most suitable person to marry, three out of five sisters achieve to get married.

Because the aim of this paper is to analyze the situations in which these three sisters went through, to find their match and also to analyze the relationships of the already married couples, the main focus and the more detailed analyses with be based on Elizabeth Bennet and her relationship with Fitzwilliam Darcy, Jane Bennet and Charles Bingley, Lydia Bennet and George Wickham, Charlotte Lucas and Mr. Collins and also the relationship of Mr. and Mrs. Bennet, Mr. and Mrs. Gardiner.

\section{UNMARRIEd In PRIDE AND PREJUdICE}

\subsection{Charlotte Lucas and Mr. Collins}

The relationship of Charlotte and Collins represents a relationship typical for the period of the eighteenth century. Their relationship is not based on love, but on finding a partner to spend their life. Charlotte, Elizabeth's best friend, was at the age of twenty- seven, and she was not lucky enough to be beautiful. Since most of the girls of the eighteenth century attended balls to find husbands, trying to 
show their physical beauty, Charlotte knew that she would not be evaluated by her intelligence. Men were considered to be above women, and since women lacked education, they were supposed to depend of their husbands. "The married women became a 'feme covert' and performed all of her actions under the 'wing, protection, and cover' of her husband" (Lewis, 2016). Mr. Collins, "was a tall, heavy- looking young man of five-and-twenty" (Austen, 1995). Shortly after Elizabeth's refusal to Mr. Collins' proposal, he proposed to Charlotte, who accepted him immediately, by believing that "happiness in marriage is entirely a matter of chance" (Austen, 1995). "Mr. Collins was not a sensible man, and the deficiency of nature had been but little assisted by education or society; the greatest part of his life having been spent under the guidance of an illiterate and miserly father; and though he belonged to one of the universities, he had merely kept the necessary terms, without forming at it any useful acquaintance. The subjection in which his father had brought him up had given him originally great humility of manner; but it was now a good deal counteracted by the self-conceit of a weak head, living in retirement, and the consequential feelings of early and unexpected prosperity... his authority as a clergyman, and his right as e rector, made him altogether a mixture of pride and obsequiousness, self- importance and humility" (Austen, 1995). Collins believed that the upper-class people were superior, had better behavior and were more elegant. He admired Lady Catherine; even though, she acted arrogantly to many people. He considered her superior and believed that she was an extraordinary woman. Whatever Lady Catherine told him, he considered it to be correct. Taking from what Lady Catherine had taught Mr. Collins, Collins considered himself superior to other people, especially the Bennets' sisters. Being present in his life for a long time, Lady Catherine was the example of perfection in the eyes of Mr. Collins only because she was rich and showed authority. Austen reflects the consequences of being educated by a woman such as Lady Catherine through Mr. Collins. He chose to marry without love and chose a partner only because he had to get married and create a family, only because he was grown enough to have a wife. Charlotte "...had gained her point, and had time to consider it...Mr. Collins, to be sure, was neither sensible nor agreeable; his society was irksome, and his attachment to her must be imaginary. But still he would be her husband. Without thinking highly either of men or matrimony, marriage had always been her object; it was the only provision for well- educated young women of a small fortune..." (Austen, 1995). Although Charlotte respected her friend, Elizabeth, so much, and she knew that Elizabeth was not happy enough for Charlotte to accept Collins's proposal, immediately after Elizabeth's refusal, again Charlotte was in need of financial security because she did not have enough materialistic conditions to be supported; as a result, her father did not have good relationships with the landed gentry. "So, in her solitude she suffers and she does not want to prolong her sufferings as she is compelled to observe her painful situation" (Haque, 2013). Charlotte reflects the woman in her society, who had no other profession and considered marriage as the only means of having a stable life. Her marriage was loveless marriage and Charlotte was aware of it, but she was happy to have "made a satisfactory adjustment to her conjugal life" (Haque, 2013).

Through this marriage Austen proves to the readers "the consequences of placing practicality before romance which was not uncommon in the eighteenth century England" (Haque, 2013). For Charlotte and Collins "marriage is a market place where they must strive to make the best bargain they can in order to conserve or improve their status of life...through her marriage she achieves what she wantsfinancial stability, status and independence in becoming a mistress of her own house...her marriage is not ideal but she is able to escape social pressure and humiliation as well as social isolation" (Haque, 2013). "...the fact that Charlotte has weighed her own options and chosen marriage as her "pleasantest preservative from want' suggests at least a degree of taste; although Mr. Collins is no prize, still...Charlotte has sufficient cultural competence to make distinctions among 'preservatives from want' "(Lambdin; Lambdin, 2000). Through the pairing, the author is able to comment on the lack of romance and passion found in the economically based marriages like that of Mr. and Mrs. Collins" (Berry, 2014).

\subsection{Lydia Bennet and George Wickham}

The relationship of Lydia Bennet and George Wickham is a relationship based on naivety and a forced marriage. Their character is described as a total contradiction, and her way of acting with her elopement brought a lot of debate in the house. As a girl of sixteen, Lydia was too much involved in gossiping, and her main aim in life was finding a husband. She was "a stout... with a fine complexion 
and good- humored countenance; a favorite with her mother, whose affection had brought her into public at an early age. She had high animal spirits, and a sort of natural self-consequence, which the attention of the officers, to whom her uncle's good manners, and her own easy manners recommended her, had increased into assurance" (Austen, 1995). Here Austen shows clearly that girls during the period of the eighteenth century were allowed to show off in public at a very early age with the intention to find an appropriate match. Since Lydia was taught to be out of her society, focusing only on flirting, Austen shows that the indulgence of mothers during the eighteenth century had a great impact in their girls, especially at an early age when they were not fully developed. Austen's use of irony in these statements shows clearly that Lydia's brain was filled with marriage opinion, and she belonged to the group of girls who could not imagine themselves unmarried. On the other hand, Wickham is described as an immature and a selfish person. He is seen as a person who was not afraid to complete his love interest immediately. "Wickham is presented as a cad, with, in the end, few forgiving qualities" (Cardell, 2012). Hazel Jones describes Wickham by saying:

Given George Wickham's sexual proclivities, we can guess what he might get up to on his visits there without his wife (2009).

Moreover, Moore describes his behavior, saying that he has "the 'primitive' or 'infantile' drives, 'amoral' traits, and a 'superiority' complex that covers a real sense of vulnerability, weakness and superiority" (1990).

Lydia's main interest relied only in the excitement of being in a relationship with someone attractive. She did not think about the fact that Wickham had no intentions to marry her. What Wickham wanted from her was just a temporary affair, which would not last long. Having a lot of debts to pay, Wickham had the least intention to marry Lydia, and the people who knew him, were all familiar to this fact. Austen reflects the sad conditions of the eighteenth century, which period involved a gender inequality where men were allowed to act in many situations and women not because they would suffer the consequences. The fact that Lydia was a young girl, brought the situation of her elopement. Here Austen expresses her revolt towards young innocent girls who were completely brainwashed by the poor mentality of that time. The fact that Darcy paid Wickham's debts obliged Wickham to marry Lydia. His debts were paid only with this condition, so he had no other choice but to accept Darcy's offer. Even though, his wish was to marry someone rich, his plans did not go the way he wanted, because his marriage to Lydia was influenced by external circumstances. He was 'a constant seducer, and has been known to seek pleasure of the flesh instead of commitment" (Cardell, 2013). Through the marriage of Lydia and Wickham, Austen presents a marriage with many contradictory characteristics, and shows that such relationships do not function. Moreover, she shows that being in love and having no love in return is not the key for a happy marriage. "While the marriage appears to be blissful, and the flirtatious Lydia seems happy and giddy with the match, Austen makes it clear that this marriage does not have the ideal level of love that should exist between a husband and a wife" (Berry, 2014). Through the marriage of Lydia and Wickham, Austen represents a marriage which is seen as unhappy, it "gains neither Lydia nor Mr. Wickham emotionally in the long run, and also the reputation of the Bennet family is stained" (Asker, 2012). By marrying Wickham, Lydia "has condemned herself to a life of misery as there will never be enough money to cover the cost of the lifestyle they both desire" (Smith, 2014). As Odmark argues: "Wickham's forced marriage to Lydia may satisfy social convention and over joy Mrs. Bennet, but the moral issue is not easily done away with" (1983).

\subsection{Jane Bennet and Charles Bingley}

The relationship of Jane and Bingley starts from the very first time when they meet each other in the ball. Jane achieves to find her ideal man immediately since their first meeting, but different circumstances keep them separated until almost the end of the novel. Taking into account the fact that Bingley was a person of a good fortune and a charming man, Jane's family thought that he could be a great match for their daughter. In the novel Mr. Bingley is described as a "gentlemanlike, lively and unreserved" (Austen, 1995), and his requirements to be satisfied are not that high. "Bingley has great natural modesty; with a stronger dependence on judgment... he is a modest man, careful and slightly shy" (Cardell, 2013). On the other hand, Jane seemed to have a very similar character to Bingley's. From the very beginning, Jane and Bingley are described as tolerable characters, and they do not change until the end. Jane was a person who did not like problems and did not show her feelings so 
freely. She did not express her feelings for Bingley either, which situation left Bingley confused. Even Charlotte, Elizabeth's friend gave remark about Jane by stating that:

...it is sometimes a disadvantage to be so very guarded. If a woman conceals her affection with the same skill from the object of it, she may lose the opportunity of fixing him...a woman had better show more affection than she feels" (Austen, 1995).

The meetings of Bingley and Jane in different balls and her stay at Bingley's house made her feel about Bingley, and fall in love with him. "The mutual attraction between Jane and Bingley begins to creep into visibility very early, but then external obstacles intervene, and the engagement takes place only near the end" (Halperin, Austen, 1975). Bingley, who lived with his sisters, began to feel the same way, but the influence that other people had in his life caused many problems and made this relationship very complicated. There had entered Darcy and Bingley's sisters who made this relationship complicated. Since Jane and Elizabeth had close relationships and discussed their personal problems together, based on the situation which was caused by the influence of Bingley's sisters, Elizabeth advised Jane to think good before taking any farther step:

"But, my dear sister, can I be happy, even supposing the best, in accepting a man whose sisters and friends are all wishing him to marry elsewhere?"

"You must decide for yourself," said Elizabeth; "and if, upon mature deliberation, you find that the misery of disobliging his two sisters is more that equivalent to his happiness of being his wife, I advise you by all means to refuse him" (Austen, 1995).

Based on these facts, we see that Bingley was influenced by the people surrounding him, and the persuasion of his friend Darcy and his sisters made him leave the place. "To convince him, therefore, that he had deceived himself, was not very difficult point” (Cardell, 2013). “...Jane and Bingley, as a couple, share the same difficulty in making choices, apart from the choice of each other, and even that choice, particularly on Bingley's side, shows a certain pliability" (Barfoot, 1982).

The letter that Jane received from Bingley's sister stating that Bingley left the place and that he might get married to Miss Darcy, made her feel hopeless. After Darcy's explanation about what had happened and after understanding that Bingley's sisters had created such circumstances to persuade Bingley leave the place, Bingley returned and was immediately invited to dine at Bennets' house. Jane's face at the moment of proposal was described by Elizabeth when " she perceived her sister and Bingley standing together over the hearth, as if engaged in earnest conversation; and had this led to no suspicion, the faces of both, as they hastily turned round and moved away from each other, would have told it all. Their situation was awkward enough; but HER's she thought was still worse. Not a syllable was uttered by either...jane could have no reserves from Elizabeth, where confidence would give pleasure; and instantly embracing her, acknowledged, with liveliest emotions, that she was the happiest creature in the world...Elizabeth's congratulations were given with a sincerity, a warmth, a delight, which words could not poorly express. Every sentence of kindness was a fresh source of happiness to Jane" (Austen, 1995). Jane Bennet's "forgiving spirit is, in fact, a neurotic inability to blame anyone, and her recourse to theories of conspiracy, when trying to find excuses for Miss Bingley's part in separating her from Mr. Bingley, is not so much good as simple- minded" (Beer, 1974). There is seen only a slight change on Jane, when she does not think about people the same way anymore. When she receives Caroline's final letter, stating that she is happy for Bingley's and Jane's engagement, Jane was "not deceived by it" (Cardell, 2013).

With the relationship of Jane and Bingley, Jane Austen's theme of marriage becomes more positive. Their relationship "is based on genuine love, understanding and a similarity of feelings and perspectives on the world" (Kalil, 2011). The marriage of Jane and Bingley is the first socially accepted marriage in the novel. Their "marriage is the automatic union of two gentle, amiable, modest, similar souls" (Halperin, 1975). Through Jane, Austen gives "a strong message of women and their lack of power, as well as keen observations on the role of marriage as a reflection of the sociological implications of society they lived in"(DiMauro, 2012). The marriage of Jane and Bingley shows that; even though, there is an interest of wealth, again this relationship is mainly based on prior affection and creates appropriate unit of personalities of both Jane and Bingley.

\subsection{Elizabeth Bennet and Fitzwilliam Darcy}

The relationship of Darcy and Elizabeth, which is one of the most important relationships in the novel, involves a relationship not based on love from the first sight. Their relationship passes through 
different obstacles until it ends up with a marriage based on true love. As Taawo states, before their final admission for true love, they both "develop as individuals. Along the road they meet with preconceptions and appearances and other thought- provoking behavior, which compels them to ransack their own selves- something that in, due course, will be what brings them closer together" (2008). The very first time when Darcy appeared at the ball hall, he left the impression that he felt very proud. He did not even accept to dance with the girls around because he thought himself superior to the people surrounding him. "The gentlemen pronounced (Mr. Darcy) to be a fine figure of a man, the ladies declared he was much handsomer than Mr. Bingley, and he was looked at with great admiration for about half the evening, till his manners gave a disgust which turned the tide of his popularity; for he was discovered to be proud; to be above his company, and above being pleased; and not all his large estate in Derbyshire could then save him from being a most forbidding, disagreeable countenance, and being unworthy to be compared with his friend" (Austen, 1995). Based on these ways of his behavior it is seen that "Darcy exhibits all the good and bad qualities of the ideal English aristocrat- snobbish and arrogant, he is also completely honest and sure of himself...While Darcy's sense of social superiority offends people, it also promotes some of his better traits" (Kalil, 2011).

On the other hand, Elizabeth was seen as an "unfailing attractive character...a beauty...expressive eyes, but what everybody notices about her is her spirited wit and her good sense... her self- assurance comes from a keen critical mind and is expressed through her quick-witted dialogue" (Kalil, 2011). Kaye- Smith and Stern say that "Along the road they meet with preconceptions and appearances and other thought- provoking behavior, which compels them to ransack their own selves- something that in, due course, will be what brings them closer together..." (1943).

The superiority of higher class women, made them see the lower class women differently. Having the intentions to win Darcy's love and affection, Miss Bingley wanted to show off her elegance by offending other women, especially Elizabeth. She judged and offended Elizabeth by considering her as having too much pride and not paying attention to her physical appearance. According to Miss Bingley, Elizabeth's "manners were pronounced to be very bad indeed, a mixture of pride and impertinence; she had no conversation, no style, no beauty...She really looked almost wild...Her hair, so untidy, so blowsy.... and her petticoat...six inches deep in mud, I am absolutely certain; and the gown which had been let down to hide it not doing its office" (Austen, 1995).

Elizabeth's character as a proud person, has been shown many times in the novel, her impulsive character did not leave other people judge her. This was even considered as the only mistake of Elizabeth, as Kalil states:

In spite of her mistake in misjudging... and her more blamable fault of sticking stubbornly to that judgment until forced to see her error, Elizabeth is usually right about people...Her confidence in her own discernment- a combination of both pride and prejudice- is what leads her into the worst errors (2011).

In spite of the fact that Elizabeth and Darcy belonged to different economical classes, again they both carried a pride which made them to be similar with each other. Their stubbornness and their direct confrontation with people made them get more affected to each other. Even though, Darcy's first impression to Elizabeth was not such pleasant, again during his frequent family visits, he began to see Elizabeth differently. Elizabeth's and Darcy's relationship began with Darcy's feelings first, because he was the first who felt about Elizabeth. When Darcy went on a family visit at Bennet's house, "Elizabeth could not help observing, as she turned over some music- books that lay on the instrument, how frequently Mr. Darcy's eyes were fixed on her. She hardly knew how to suppose that she could be an object of admiration to so great a man; and yet that he should look at her because he disliked her, was still more strange. She could only imagine, however, at last that she drew his notice because there was something more wrong and reprehensible, according to his ideas of right, than in any person present. The supposition did not pain her. She liked him too little to care for his approbation" (Austen, 1995).

Fate sent Elizabeth to visit her sister Jane in Netherfield, which was a great chance for her to meet Darcy "To Mr. Darcy it was welcome intelligence- Elizabeth had been at Netherfield long enough. She attracted him more than he liked...He wisely resolved to be particularly careful that no sign of admiration should now escape him, nothing that could elevate her with the hope of influencing his 
felicity; sensible that if such an idea had been suggested, his behavior during the last day may have material weight in confirming or crushing it" (Austen, 1995). Being a self convinced person and having the right of veto, Elizabeth refused everything and everyone that she thought was not appropriate for her. Elizabeth was "not representative of a typical woman of her time, because of her rejection of the contemporary image of the accomplished woman...she (did) not allow herself to marry unless it (would) increase her chance of happiness, despite jeopardizing her chance at a secure home...she really (was) a mistress over herself. She (did) not let herself be convinced that she should be any less respectable merely because of her faulty list of accomplishments or lower social status" (Taavo, 2008). Her ideals for a happy marriage were based on true love and feelings, and since she was a person who did not love Collins and was sure that Collins felt nothing for her, she refused his proposal without any doubt. Elizabeth, as the heroine of the novel, is seen as an "'arch"” (Beer, 1974) character, which means, she says "no, when (she) means 'no' and 'yes' when (she) means 'yes' (Beer, 1974). The way how Darcy began to feel for Elizabeth, changed him as a person. He began to understand that his pride and stubbornness were not welcomed in her mind, so he changed in order to win her love. He wanted to spend his time with Elizabeth and used all his chance to get closer to her." ...why Mr. Darcy came so often to the Parsonage, it was more difficult to understand. It could not be for society, as he frequently sat there ten minutes together without opening his lips; and when he did speak, it seemed the effect of necessity rather than of choice- a sacrifice to propriety, not a pleasure to himself...Colonel Fitzwilliam's occasionally laughing at his stupidity, proved that he was generally different, which her own knowledge of him could not have told her; and as she would liked to have believed this change the effect of love, and the object of that love her friend Eliza..."(Austen,1995).

The time when Elizabeth had began to get closer to Darcy, was followed by a new complication of their relationship. It was the time when Elizabeth had a conversation with Mr. Wickham. It was a conversation which changed completely Elizabeth's opinion about Darcy. The conversation, in which Wickham had mentioned to Elizabeth that Darcy had tried to take his wealth and that Darcy had persuaded Bingley to leave the place and not marry Jane was a great shock for Elizabeth. Being influenced by Wickham's words and without asking for any explanation, Elizabeth refused Darcy's proposal. When Elizabeth "flatly (turned) down his marriage proposal and (told) him that it was ungentlemanly, Darcy is startled into realizing just how arrogant and assuming he (had) been" (Kalil, 2011). Elizabeth's prejudiced mind left Darcy speechless, but the letter received by Darcy destroyed her completely. Being a reserved man, Darcy left Elizabeth without saying any word, and wrote her only when he felt he was ready for an explanation, as he discovered that Elizabeth was given wrong information by Wickham. Moreover, Darcy gave a farther explanation regarding Jane's relationship and Wickham's debts. Darcy's explanation made Elizabeth change her opinion, and she accused herself for misjudging other people. Elizabeth was sorry for the pain that she had caused to Darcy, and blamed herself by saying:

How despicably I have acted!'I, who have prided myself on my discernment! I, who have valued myself on my abilities! Who have often disdained the generous candour of my sister, and gratified my vanity in useless or blameable mistrust! How humiliating is this discovery! Yes, how just a humiliation! Had I been in love, I could not have been wretchedly blind! But vanity, not love, has been my folly (Austen, 1995).

Now, that Darcy had given explanation and Elizabeth had understood that her prejudice had made things complicated, Elizabeth saw Darcy in a more positive light and this made her fall in love with him. Now, that Elizabeth had had a fight with Darcy, and that Darcy had explained everything to her about what had happened, both of them had changed. The love for each other had made them different people. Elizabeth underwent a change, and Spacks reads her 'development as a 'paradigm of adolescent potential fulfilled'. Elizabeth discovers 'the positive advantages of maturity over childishness; even in a society whose rigidities offer protection to the continued immaturity characteristic of most of its members" (Spacks, 1975). Darcy openly expressed the love and affection for Elizabeth by stating to Miss Bingley: “...it is many months since I have considered her as one of the handsomest women of my acquaintance" (Austen, 1995). On the other hand, Elizabeth "began to comprehend that (Darcy) was exactly the man, who, in disposition and talents, would most suit her. His understanding and temper... would have answered all her wishes. It was an union that must have been to the advantage of both; by her ease and liveliness, his mind might have been softened, his 
manners improved; and from his judgment, information, and knowledge of the world, she must have received benefit of greater importance" (Austen, 1995). The second proposal of Darcy could not end up differently but with the acceptance of Elizabeth. After all these events, Darcy was "willing to marry into a family with three silly daughters, an embarrassing mother, and Wickham as a brother-inlaw...he (became) more easygoing about other people's faults because he (was) now aware of his own" (Kalil, 2011). Through Elizabeth, Austen characterizes a self- confident girl and a girl facing different circumstances to achieve her goals. Based on Elizabeth's character, as natural and stubborn, Austen represents the adequate girl, who is willing to acquire her accomplishments. She is represented as a person, who does not make choices based on security but based on love and affection. She has the courage to refuse her mother's pressure to marry for money and not for love. Focusing on the unhappy marriage of her parents and on the happy marriage of her uncle's marriage, Elizabeth judged marriage differently. "For Austen's readers, Elizabeth represents an ideal view of the world..." (Kalil, 2011). Through Elizabeth, Austen reflects the "generally advocated comportment of her own time" (Taavo, 2008). Elizabeth's liveliness is one of the qualities which made her win Darcy. "She is capable of both complex ideas and impressions, and has a stubborn inflexibility of pre- ordained conclusions... She is a heroine who possesses high moral standards, has strong convictions, and an engrained intuition... What wins Darcy over to her is her basic sincerity, her honesty in approaching reality, and her ability to speak her mind" (Blanchard, 2015).

In her novel, Austen describes the relationship of Darcy and Elizabeth as a more difficult relationship. She describes it as a "complex affair: both parties are sharp, critical, strong- minded, and given to firm stands upon initial grounds that need modification...they have to work through a barrier- ground of unfavorable judgments, misunderstandings, and self- justifications" (Halperin, 1975). "...the relationship between Elizabeth and Darcy is a love based on intelligence and a spirited nature" (Smith, 2014). Through the marriage of Darcy and Elizabeth, Austen conveys a message that love prevails everything; it even changes people and makes them understand and learn from their own mistakes. Love is the one which makes people feel happier in their relationship. Austen presents a relationship not typical for the couples of the eighteenth century, with the intention to show to the world that relationships based on love are strong enough to make people better ones and change them for good.

\section{MARried In Pride And Prejudice}

\subsection{Mr and Mrs. Bennet}

The relationship of Mr. and Mrs. Bennet is described as an unhappy marriage. Based on Mrs. Bennet, Austen says about her: "she was a woman of mean understanding, little information, and uncertain temper" (Austen, 1995). "Silly, emotional, and irrational, Mrs. Bennet's behavior does more to harm her daughters' chances at finding husbands than it does help" (Kalil, 2011).

In the novel, Mrs. Bennet is seen as a vulgar person, whose main aim was to have her daughters married. From the very opening of the novel, we see Mrs. Bennet being interested in Bingley when he arrives at Longbourn. When she understood of his coming, she said to her husband:

Oh! Single, my dear, to be sure! A single man of large fortune; four or five thousand a year. What a fine thing for our girls! (Austen, 1995).

Mrs. Bennet was a gossipy and an uneducated woman, who was unwilling to understand her husband's irony, and who was willing to sacrifice her daughters' health only for the sake of their marriage. Mrs. Bennet's selfishness and her wish to get her daughters married was seen when her daughters returned from Bingley's house. "They were not welcomed home very cordially by their mother. Mrs. Bennet wondered at their coming, and thought them very wrong to give so much trouble, and was sure Jane would have caught cold again" (Austen, 1995).

Mrs. Bennet was an envious person and hated everyone that got married before her daughters. When Charlotte accepted Collins' proposal, Mrs. Bennet's attitude changed completely. "Mrs. Bennet was really in a most pitiable state. The very mention of anything concerning the match threw her into an agony of ill- humour, and wherever she went she was sure of hearing it talked of. The sight of Miss Lucas was odious to her. As her successor in that house, she regarded her with jealous abhorrence. Whenever Charlotte came to see them, she concluded her to be anticipating the hour of possession; and whenever she spoke in a low voice to Mr. Collins, was convinced that they were talking of the Longbourn estate..." (Austen, 1995). 
Mrs. Bennet could not express her happiness after the forced marriage of Wickham and Lydia. She could "hardly contain herself. As soon as Jane had read Mr. Gardiner's hope of Lydia's being soon married, her joy burst forth, and every following sentence added to its exuberance" (Austen, 1995). Moreover, when Darcy proposed to Elizabeth for the second time, and when Elizabeth accepted his proposal, Mrs. Bennet's reaction was:

Good gracious! Lord bless me! Only think! Mr. Darcy! Who would have thought it! And is it really true? Oh! My sweetest Lizzy! how rich and how great you will be! What pin- money, what jewels, what carriages you will have! Jane's is nothing to itnothing at all. I am so pleased- so happy. Such a charming man!- so handsome!so tall!- oh, my dear Lizzy! (Austen, 1995).

On the other hand, Mr. Bennet is described as the head of the family, but he held a position which was abused. Based on the traditional customs, he was asked for things at home and Mrs. Bennet was the manager. Their duties were done separately, and Mr. Bennet spent most of his time reading rather than staying and talking to his wife. Mr. Bennet did not seem happy with his marriage, and this was expressed when he said to his daughter Elizabeth: "My child, let me not have the grief of seeing you unable to respect our partner in life" (Austen, 1995). The marriage of Mr. and Mrs. Bennet is described as "tedious and lifeless" (Taavo, 2008). Mr. Bennet "captivated by youth and beauty, and that appearance of good humour which youth and beauty generally give, had married a woman whose weak understanding and illiberal mid had very early in their marriage put an end to all real affection for her. Respect, esteem, and confidence had vanished for ever; and all his views of domestic happiness were overthrown...Mr. Bennet...was fond of the country and of books; and from these tastes had arisen his principal enjoyments. To his wife he was very little otherwise indebted, than man would in general wish to owe to his wife; but where other powers of entertainment are wanting, the true philosopher will derive benefit from such as are given" (Austen, 1995). Having become disappointed in his marriage, Mr. Bennet's opinion about marriage had changed, and he chose not to advise his daughters to marry for money. When Elizabeth wanted to marry Darcy, Mr. Bennet said to her:

He is rich, to be sure, and you may have more fine clothes and fine carriages...But will they make you happy? (Austen,1995).

Mr. Bennet could not find peace with the way his wife looked after her children and this made him ignore his family. "His disappointment in his wife's illiberal mind drove him apart from his family and thus love and affection were not present in their marriage" (Chalupova, 2012). Mr. Bennet was so fed up of his wife, so, most of the times he undervalued her and talked to her with cruel words:

"...you have no compassion on my poor nerves"

"You mistake me, my dear. I have a high respect for your nerves. They are my old friends. I have heard you mention them with consideration these twenty years at least" (Austen, 1995).

The unequal marriage resulted on Mr. Bennet being in a total isolation, and Mrs. Bennet as "a completely disorganized woman" (Austen,1995). Austen describes both Mr. and Mrs. Bennet as married to wrong partners. Their relationship lasted only for the sake of the tradition during the period of the eighteenth century, when divorce was a big issue to be discussed and difficult to be mentioned. Mr. Bennet did not do anything to advise his wife and improve her mistakes, educate her or teach her to become less vulgar. Instead, he laughed at her stupidity, making her a woman of fun in front of other people. Mr. Bennet is seen as a disappointed person in his marriage. The independence of Mr. and Mrs. Bennet, their lack of each other's companionship and the absence of each other's desire to be close to each other, are the issues which make this marriage unhappy. Austen uses the irony to show that these marriages are very formal and do not possess feelings towards each other. The lack of the desire to spend the time with your lifetime partner and the lack of the willingness to show to the world and yourself that your partner is someone who should be respected are all things which show that these kinds of marriages would not be followed because they destroy the partner and the family.

\subsection{Mr. and Mrs. Gardiner}

Mr. and Mrs. Gardiner's marriage reflects a different type of marriage compared to Mr. and Mrs. Bennet's marriage, for the fact that it was based on love, affection and respect. In contrast to Mrs. Bennet, her brother Mr. Gardiner was a "sensible, gentlemanlike man, greatly superior to his sister, as well by nature as education" (Austen, 1995). On the other hand, Mr. Gardiner was married to a 
woman who was "both estimable and a great favorite of her nieces" (Thaler, 2009). Mrs. Gardiner is described as an "amiable, intelligent, elegant woman" (Austen, 1995). Mrs. Gardiner did not like getting involved in gossiping and never advised her nieces to find a husband without love and affection. Elizabeth, who had closer relationships with Mrs. Gardiner, found her to be very understanding and talked freely without any hesitation. When Elizabeth went with Gardiners in Derbyshire, she was so happy because she knew that she would find enjoyment, "suitableness as companions, a suitableness which comprehended health and temper to bear inconveniencescheerfulness to enhance pleasure- and affection and intelligence, which might supply it among themselves if there were disappointments abroad" (Austen, 1995). "Mr. Gardiner fought his way up in society through his work and his marriage to a sensible and intelligent woman. And his efforts serve to suggest that he strives to become not only a gentleman- tradesman, but also a gentleman" (Thaler, 2009). Through Mr and Mrs. Gardiner, Austen tries to show a model for a happy marriage and a helper for younger generation.

Relying on Gardiner's marriage and considering their marriage appropriate, Elizabeth followed their example by marrying for love and not for interest. Through Mr. and Mrs. Gardiner's marriage, Austen reflects a happy marriage and conveys a message that the younger generation should marry for love and choose a partner based on mutual affection. In contrast to Mr. and Mrs. Bennet's marriage, Mr. and Mrs. Gardiner's marriage represents the harmony that people can achieve through a mutual respect. In contrast to Mrs. Bennet, Mrs. Gardiner "never rudely undermines her husband's authority. They have rational conversations, and value each other's opinion in different situations" (Berry, 2014). Austen shows that having a common language, sharing ideas and opinions and coming to the best idea to solve a problem makes a marriage more successful, and happier which influences greatly our successors and the relationship within the family.

\section{CONClusion}

To conclude, in her novel Pride and Prejudice, Austen represented the limited and unsatisfactory prospects of Charlotte, who was obliged to marry due to her lack of education and her inability to secure her own life. Through Charlotte, Austen reflects the conditions of poor, unmarried girls at the time when she lived. Austen depicts Charlotte as a character in her novel to show that if girls could get a proper education, they would have better choices in their lives. Their future would not depend on marriage based on interest and survival for life. Lack of education and the influence of parents to make their daughters look physically pretty in order to attract men, made girls to take wrong steps. This happened with Lydia, a very naïve girl whose main aims in life were her appearance and marriage. Her naivety leads to her elopement with Mr. Wickham without thinking about consequences. The marriage of Wickham and Lydia represents a marriage with many contradictory characteristics, and shows clearly that such marriages never function. The heroine of the novel, Elizabeth, represents completely a different type of a woman who was willing to marry only if there existed true love and mutual affection. Elizabeth's intentions were not to marry the first man who came to ask her hand. She refused Mr. Collins' proposal without any doubt, believing that she would never marry someone she did not love. Through Elizabeth, Austen shows a woman who made her own decisions and opposed other people when she thought they were wrong. Elizabeth's relationship with her partner represents a true love. Even though their relationship was based on many misunderstandings and disagreements, again their love grew despite the differences. Austen depicts Elizabeth's relationship with Darcy to show the type of love where they conquer all things.

Based on the married couples, Austen depicts couples married for interest and couples married for love, emphasizing the bad consequences of being married just for economical interest. She depicts the marriage of Mr. and Mrs. Bennet to show that these kinds of marriages are very formal and lacking the love will never bring happiness to the couple. On the other hand, Austen depicts the marriage of Mr. and Mrs. Gardiner to show the harmony that people can achieve through mutual respect and love. As Beer mentions: "the novel in particular, without benefit of anyone's argument, can show quite precisely how things are or were..." (ix). Austen shows that those married only for physical attraction or money cannot last in their marriage.

\section{REFERENCES}

[1] Asker, R, 2012, Money and Love in Jane Austen's Pride and Prejudice. Retrieved from http://www.divaportal.org/smash/get/diva2:517202/FULLTEXT01.pdf on 17 June, 2017

[2] Austen, J.1995. Pride and Prejudice. New York: Modern Library. 
[3] Barfoot, C.C. The Thread of Connection. Aspects of Fate in the Novels of Jane Austen and Others. Rodopi. Amsterdam.

[4] Beer, P. 1974, Reader, I Married Him. Barnes\& Noble Books, A Division of Harper \&Row Publishers, New York, Hagerstown, San Francisco, London, p.46

[5] Berry, K.2014, A Love that Lasts: Jane Austen's Argument for a Marriage Based on Love in Pride and Prejudice. Liberty University. P.19, 20.

[6] Blanchard, W, 2015, Pride and Prejudice (MAX Notes Literature Guides), Research \& Education Assoc. p.68

[7] Cardell, M. 2013. Love and Marriage in Jane Austen's Novels. GUPEA. p.7

[8] Chalupova, J, 2012, Happily Ever After? Or the Condition of Marriage in Jane Austen's Novels. Retrieved from https://is.muni.cz/th/333079/pedf_b/BARCHELOR_THESIS.pdf on June 17, 2017

[9] DiMauro, M. 2012, An Analysis of the Marriages in Pride and Prejudice. Retrieved from http://www. brighthubeducation.com/homework-help-literature/57838-analysis-of-marriages-in-pride-and-prejudice/ on 17 June, 2017

[10] Dobosiova, M, 2006, Marriage and Human Relationships in the Eighteenth Century England, Masaryk University, p.12-15

[11] Halperin, J. Austen, J, 1975. Jane Austen: Bicentenary Essays. CUP Archive, p.135

[12] Haque, S. 2013. Charlotte Lucas's Practical Approach to Marriage and the Conditions of Women of Her Society in Jane Austen's Pride and Prejudice. IOSR Journal of Humanities and Social Science, Volume 7 , Issue 4. p.38,39,40

[13] Jones, H, 2009. Jane Austen and Marriage. A\&C Black. p.50

[14] Kalil, M. 2011. CliffNotes on Austen's Pride and Prejudice. Houghton Mifflin Harcourt, p.65

[15] Kaye- Smith, Sh, Stern, G.B. 1943. Talking of Jane Austen. London, Toronto, Melbourne and Sydney: Casell and Company.

[16] Lambdin, C; Lambdin, R.T, 2000. A Companion to Jane Austen Studies, GREENWOOD PRESS, Westport, Connecticut, London, p.43-45

[17] Lewis, J.J.2016. Blackstone Commentaries, Retrieved from https://www.thoughtco.com/blackstonecommentaries-profile-3525208 on June 17, 2017

[18] Moore, R. 1990. Warrior, King, Magician, Lover. San Francisco.

[19] Odmark, J. 1983. An Understanding of Jane Austen's Novels. Oxford: Blackwell.

[20] Smith, T, 2014. Jane Austen's Pride and Prejudice. Lulu.com.

[21] Spacks, P.M. 1975. The Female Imagination. New York: Avon Books.

[22] Strohmeier, S, 2012, Jane Austen's Representation of Marriage in "Pride and Prejudice", GRIN, p.4

[23] Taavo, A. 2008. Eighteenth- Century Female Conduct in Jane Austen's Pride and Prejudice- An Analysis of Elizabeth Bennet. Lund University. p.8

[24] Thaler, J. L. 2009. Jane Austen Society of North America, Retrieved from http://www.jasna.org/essay contest/2009/undergraduate.html on June 17, 2017.

\section{AUTHOR'S BIOGRAPHY}

Eljvira Kica, has more than eight years experience in ESL Teaching, where she has been involved in developing and implementing the curriculum for Albanian students living in R. Macedonia. Moreover, Eljvira has been involved in a teaching position at State University of Tetovo, teaching grammar as well as writing and reading courses to students studying English Language and Literature. With her PhD in English Language and Literature at South East European University, R. Macedonia, her areas of interest include Teaching the English and American Literature of different periods, Literary Theory and Criticism and Comparative Literature.

Citation: Eljvira Kica. Unmarried and Married in Jane Austen's Pride and Prejudice. International Journal on Studies in English Language and Literature (IJSELL), vol 5, no. 11, 2017, pp. 4-13. doi: http://dx.doi.org/ 10.20431/2347-3134.0511002.

Copyright: (C) 2017 Authors. This is an open-access article distributed under the terms of the Creative Commons Attribution License, which permits unrestricted use, distribution, and reproduction in any medium, provided the original author and source are credited. 